\title{
Physiology and Rumen Microbial Ecology of Goats Fed Municipal Organic Solid Wastes Treated with Diastic Microbes from Snail (Achatina achatina)
}

\author{
Agida, Christopher Agboje ${ }^{1 *}$, Essien Ekpenyong Nsa ${ }^{2}$, \\ Uduakobong Essien John', Constance Ihuoma Adje ${ }^{3}$, A. N. Chukwuemela', \\ Blessing Adanma Ukonu' ${ }^{1}$ and Anigbogu, Nnamdi Mbanefo ${ }^{1,4}$ \\ ${ }^{1}$ Department of Animal Nutrition and Forage Science, Michael Okpara University of Agriculture, \\ Umudike. P.M.B. 7267, Umuahia, Abia State, Nigeria. \\ ${ }^{2}$ Department of Animal Science, University of Calabar, Nigeria. \\ ${ }^{3}$ Department of Animal Science, Faculty of Agriculture, University of Port Harcourt, Nigeria. \\ ${ }^{4}$ Life-Enzyme and Fine Chemical Research (Waste Management, Utilization and Pollution Control), \\ Michael Okpara University of Agriculture, Umudike. P.M.B. 7267, Umuahia, Abia State, Nigeria.
}

Authors' contributions

This work was carried out in collaboration among all authors. All authors read and approved the final manuscript.

Article Information

DOI: 10.9734/ARRB/2021/v36i1030438

Editor(s):

(1) Dr. Paola Angelini, University of Perugia, Italy.

Reviewers:

(1) Brishketu Kumar, Nau, India.

(2) Nafly Comilo Tiven, University of Pattimura, Indonesia. Complete Peer review History: https://www.sdiarticle4.com/review-history/70290

Original Research Article

Received 01 May 2021

Accepted 03 July 2021

Published 18 October 2021

\begin{abstract}
The experiment was conducted with the objective of providing more information on the physiology and rumen microbial ecology of goats fed municipal organic solid waste treated with Diastic microbes of snails (Achatina achatina). The study was on the treated and untreated municipal organic solid waste as components of experimental diet. Balanced rations containing diets; $A=45 \%$ untreated municipal organic waste $(\mathrm{UMOW}), \mathrm{B}=45 \%$ treated municipal organic waste (TMOW), and $\mathrm{C}=70 \%$ treated municipal organic waste (TMOW), with wheat offal, palm kernel cake, and molasses used to balance the diets. Where grass/legume ratio of 3 parts of Panicum maximum and 1 part of Centrocema were fed across treatments at the same proportion. The three rations were fed to 18 unsex Red Sokoto goats aged between 6 to 7 months, with an average weight of $8.01 \pm 2.50 \mathrm{~kg}$. They were housed in pens, on a floor space of 0.5 to $0.75 \mathrm{~m}^{2}$ in a completely randomized designed experiment replicated six times and fed for
\end{abstract}


a period of 52 days. The results were separated according to the parameters of rumen physiology $(\mathrm{pH}$, total volatile fatty acids, acetic, propionic, butyric acids and ethanol, and rumen ecology (bacteria, protozoa, and fungi, which are mainly anaerobic microbes). The investigations revealed that microbial (bacteria, protozoa and fungi) load counts were significantly $(p<0.05)$ influenced by dietary treatments. While the total volatile fatty acids (TVFA), acetic, butyric and propionic increased $(p<0.05)$ except for the TVFA and the propionic acid that showed numerical $(p>0.05)$ increased levels of (TMOW). The $\mathrm{pH}$ levels improved $(p>0.05)$ between 6.7 to 6.8 where the rumen electrolytes $(\mathrm{Ca}, \mathrm{Na}$ and $\mathrm{K}$ ) increased $(p<0.01)$ with increased levels of TMOW. Rumen moisture, dry matter and fat content were $(p<0.01)$ influenced by TMOW diets while ash content was $(p<0.01)$ influenced by the TMOW. Crude protein, ether extract, crude fibre and carbohydrate were not affected $(p<0.01 ; p<0.05)$ affected. It is good to note that, the microbial community of snail used in the pre-feeding fermentation of municipal organic waste had influence in the physiology and rumen microbial ecology at interface with the goat, enhanced improved the organic matter degradation and feed quality, of the highly fibrous municipal organic solid waste.

Keywords: Physiology; rumen ecology; diatic-microbes; municipal organic waste; red sokoto goats; Achatina achatina.

\section{INTRODUCTION}

The digestive tract of ruminants is an immunologically active organ system, which is constantly exposed to multitude of exogenous and endogenous stimuli, which is a home to a complex and diverse ecosystem of microbes known as microbiome or microbiota [1]. Rumen microbes can be assigned to different functional groups of microbial-enzymes, for the decomposition of municipal organic waste (cellulolytics, amylolytics, proteolytics, lignolytics, fibrolytics, etc.), they degrade wide variety of feed components and further metabolize some of the products formed by other microbes [2]. Rumen microbial community is determined by morphological, physiological and behavioural, that evolved with different feeding strategies in the various ruminant lineages [3]. Improvement in the ability of the rumen microbiota in goats to degrade sawdust cell wall, is highly desirable and can lead to better goat production [4,5], improve weight gain, feed conversion efficiency and economic benefit on cane rat [6]. A complex community of fibrolytic microorganisms catalyzes the degradation of fibre in the rumen [7]. Fibre digestion in the rumen of goats is not optimal, as it is supported by the fact that, fibre recovered from the feces is fermentable. This view is confirmed by the knowledge that mechanical, chemical, exogenous enzymes pretreatments [5], and plant lignin composition modification by the genetical manipulation to improve fibre degradation [7]. The rumen is an ideal microbial habitat because the conditions that exist are conducive for the survival and growth of microorganisms [8,4]. The number of bacterial species present in the gastrointestinal tract of ruminant varies depending on the diet, feeding strategy and geographical location and has been estimated to be more than 5,000 [1]. The rumen functions of goat which is similar to other ruminant species, as related to their feeding systems. Fibrous biomass consumed by goat is fermented by microbes (bacteria, fungi, and protozoa) which is the ruminant distinctive ecology systems and are converted to the volatile fatty acids (acetic, propionic and butyric acids) and other fermented gases (methane and carbon dioxide) and ammonia with the product of heat, which is the major physiological component of the rumen environment.

Municipal wastes are highly heterogeneous with variable physical characteristic content depending on the sources, which are; food and vegetable wastes, yard waste, plastics, papers, wood, metals, leather, textiles, batteries, inert materials $[9,10]$. Several studies indicate that much of the municipal solid waste from developing countries generated are; $55-80 \%$ households, $10-30 \%$ commercial or market areas and varying quantities from industries, institutions among others $[11,12,13,10]$. Generally, the rumen environment provides growing conditions suitable for the development of microorganisms for the decomposition of organic wastes, the activity of each species that participates in the interaction applies selection pressure to the others [14,15]. These microbial species and activities have shown to be affected by levels of feed intake and frequency of feeding 
$[5,16,17]$. This suggests that, it is possible to manipulate the composition of ruminal microbial community by diet and management, also the host may have effect on selecting rumen bacteria $[18,19]$. This indicates the possibility to breed selected rumen microbial organisms for better performance.

The study of nutritional physiology as in this study has focused on these host-associated microbial communities (diastic microbes); metagenomics offers an opportunity to understand their physiological role and evolutionary significance [20]. This is to increase in the area of comparative studies in exploring microbial diversity of complex communities (goat rumen) and to better understand and obtain the microbial systems through information from genomics and metagenomics data $[21,22,23]$.

Snails fed on plant biomass, their guts which depends predominantly on the metabolic activities of the gastro-intestinal microflora this evolved for years to digest lignocellulosic biomass with extraordinary efficiency [24,4]. Microbial communities in stream ecosystems are the trophic foundations for food webs and energy flow, occupying nearly all functional groups that turn over nutrients from municipal organic waste and playing a central role in recycling the detrital pool into energy for the animal metabolic processes [25]. Nevertheless, the most important groups of the heterotrophic microbial communities, a suit of microscopic prokaryotes and eukaryotes that decompose organic matter are consumed by organisms of higher trophic levels. The productivity of these microorganisms can be quantified to estimate the overall productivity of stream environment if fed municipal organic waste [6]. The main targets of microbialbiotechnology prospects as in this study is to search for an innovative biocatalyst to breakdown complex polysaccharides, lignin and cellulose of sawdust complex cell walls for the release of beneficial biochemicals (protein, vitamins, total volatile fatty acids, acetic, propionic, butyric acids, and electrolytes) for goat nutrition [5], using diastic microbes of Achatina achatina.

\section{MATERIALS AND METHODS}

\subsection{Experimental Site}

The study was conducted at the Sheep and Goat Unit of the Teaching and Research Farm,
Michael Okpara University of agriculture, Umudike, Abia state, Nigeria. The site lies between latitude $05^{\circ}-29^{\circ}$ North and longitude of $7^{\circ}-32^{\circ}$ East, and at an altidude of $123 \mathrm{~m}$ above sea level. It is ecologically situated in the rainforest zone of the Southeast of Nigeria (Keay, 1959) with annual rainfall of $2177 \mathrm{~mm}$, temperature of $22^{\circ} \mathrm{C}-36^{\circ} \mathrm{C}$, and relative humidity of $50 \%-90 \%$ [26].

\subsection{Sorting, Sampling, Storage and Sample Preparation}

In this study about 2 tonnes of householdsorted organic solid waste from Umuahia municipality were used. The wastes were collected from households and market areas within seven (7) days in March 2012. The plastic bags into which the waste was placed for collection were cut up mechanically and sorted manually. Some parts of the metal impurities were removed using magnetic separation. Air dried for 14 days before grinding. The waste was milled in a Meatmincer (Palmia, $18.5 \mathrm{~kW}$ ) to a maximum particles size of $13 \mathrm{~mm}$; and $5 \mathrm{~kg}$ of the waste packed in polyethene bags (with $3 \%$ butyl acrylate added in ten (10) packs carton). The samples for chemical analysis were taken from every 10 cartons for the study. The waste was immediately stored at $24^{\circ} \mathrm{C}$ and frozen. All samples were dried at $55^{\circ} \mathrm{C}$ in a draft oven and ground in a Wiley mill to pass through a $1 \mathrm{~mm}$ sieve prior to chemical analysis.

\subsection{Chemical Analyses}

All chemical analysis for the study was determined by the method of the Association of Official Analytical Chemist [27]. The dry matter and ash were determined by conventional gravimetric as adopted by Jennische and Larsson [28]; while the crude fat was determined as described by Hassan and $\mathrm{El}$ Tinay [29]. The cellulose, hemicellulose and lignin were determined as outlined by Van Soest [30]. However, starch was determined enzymatically with thermostable amylase and amyloglucosidase as described by Nordkvist, [31]; Bengtsson and Larson [32]. Sugar expressed as sucrose was determined enzymatically based on the studies of Bengtsson and Larson [32], and Anigbogu et al., [33]. Carbon and the total nitrogen content were determined by dry combustion at $14^{0 \mathrm{C}}$ with a CNS 2000 from LECO Equipment Corporation. While gross energy was 
determined by using an automatic bomb calorimeter (LECO AC 300) (Swedish standard 187182). Analysis of electrolytes, was done with an inductively coupled plasma emission spectrometer (JY $50 \mathrm{P}$, Instrument S.A; Division Jobin-Yvon, Longjumean, France) after wet ashing with a mixture of concentrated perchloric and nitiric acids [33]. Wet ashing with nitric acid was also tested.

\subsection{Preparations of Starter Inoculum}

The starter inoculum used was prepared in the laboratory using fermentation vat (Volume 3.5 litres), the following materials were measured and added to the vat, $500 \mathrm{~g}$ of untreated municipal organic waste as substrate, $100 \mathrm{ml}$ of diastic-Microbes suspension with the addition of 0.5 litre water, then stirred to obtain a homogeneous mixture. The mixture was closed and kept at room temperature of $23.1^{\circ} \mathrm{C}$ to $24.6^{\circ} \mathrm{C}$ for 10 days. Thereafter, the fermented dough was stored for the study $[34,4,5]$.

\subsection{Preparation of Treated Municipal Organic Waste ((TMOW)}

The treated municipal organic waste (TMOW), (Diastic microbes degraded municipal organic waste) was prepared using $20 \mathrm{~kg}$ municipal organic waste placed in fermentation vat (Capacity 100 litres) with 20 liters of water and $2 \mathrm{~kg}$ fermented dough previously prepared as starter inoculums for the study and then homogenously mixed. The sample was sealed in the vat and allowed to ferment for 10 days at room temperature of about $23.1^{\circ \mathrm{C}}$ to $24^{\circ \mathrm{C}}$. After which the fermented product (TMOW) was sun-dried, analyzed and stored for the feeding trial.

\subsection{Experimental Animals and Diets}

Eighteen (18) Red Sokoto goats between aged 6 to 7 months with an average average weight of about $8.01 \pm 2.50 \mathrm{~kg}$ were used for the study. They were housed in pens, on a floor space of 0.5 - 0.75 square meters, with 4 - 5 linear inches feeding space, on well ventilated and cemented floor in intensive feeding system, of wish water and feeding were given ad-libitum. To prevent the accumulation of excreta in the pens the floor was spread with wood shavings as bedding material. The goats were quarantined for 3 weeks to observe their health condition, then treated against helminthes and ecto-parasites using IVOMEG before they were fed the experimental diets [5]. The experimental diets consist of Diet $A=45 \%$ Untreated municipal organic waste, Diet $\mathrm{B}=$ $45 \%$ Treated municipal organic waste, and Diet $\mathrm{C}=70 \%$ Treated municipal organic waste, where wheat offal, palm kernel cake, and molasses were used to balance the diets as shown in Table 1, where mixed grass/legumes (mainly 3 parts of Panicum maximum and 1 part of Centrocema pubescens were provided for the study.

\subsection{Experimental Design and Management}

The eighteen (18) Red Sokoto goats were divided into 3 groups according to their initial body weights and assigned to the 3 dietary treatments 6 replicates in a Completely Randomized Design. Each group was given basal diet of $0.5 \mathrm{~kg} / \mathrm{head}$ of mixed grass/legume (mainly 3 parts Panicum maximum and 1part Centrosema pubescens) and concentrate containing municipal organic waste as shown in Table 1. Weighed quantities of concentrate and hays were offered daily, separately at 7:30am and 4:30pm, respectively, to avoid selective intake of the diets.

\subsection{Rumen Microbial Load Count Determination}

The rumen fluid and the rumen contents of the experimental Red Sokoto goats were collected as samples using slaughter experiment techniques, by opening of the stomach to collect the samples and then sundried for analysis to determine the total microbial count load. The pour-plate method as described by McSweeney and Mackie, [35] was used to determine the rumen microbial load. Three animals from each of the treatment were stunned, slaughtered and rumen content collected according FOA and HIS, [36]. One gram of each sample was suspended into $9 \mathrm{ml}$ of sterile distilled water in a McCartney bottle to give 10 mils dilution. Serial dilutions were made up to $10^{\prime 3}$ and each dilute of the samples were plated under duplicate using pour plating techniques. This was done by transferring $1 \mathrm{ml}$ from each McCartney bottle into two different dishes, and then pours about $15 \mathrm{ml}$ of the nutrient agar media on each sample. Incubation of microorganisms was done in an incubator for 48 hours at $37^{\circ} \mathrm{C}$, after which, the 
colonies appearing on the agar plates were counted using a tally counter and hand lens. The average colony obtained from the countable duplicate plate was expressed as colony forming unit per gram $(\mathrm{cfu} / \mathrm{g})$.

\subsection{Statistical Analysis}

All data gathered at the end of the studies were analyzed using the analysis of variance (ANOVA) of Complete Randomized Design (CRD) [37]. The mean separation for significant effect was done using Duncan's New Multiple Range Test, as described by Gomez and Gomez [37].

\section{RESULTS}

\subsection{Microbial Load Count in Rumen Content}

In the experiment, microbial community evaluated were bacteria, protozoa and fungi as presented on Table 2. The mean bacteria cell count was high $(p<0.05)$ as in treatment $C$, followed by treatment $A$, while the lowest was obtained in treatment B. Protozoa cell load showed higher $(p<0.05)$ for treatment $B$, and statistically similar as in treatments $A$ and $C$. Where the fungi load count was numerical the same in treatments $A$ and $C$, and showed poor results in treatment $B(p<0.05)$.

\subsection{Rumen pH, Total Volatile Acids, Acetic and, Butyric acid, propionic and Ethanol}

Table 3, present rumen $\mathrm{pH}$, total volatile acids, acetic, butyric acids and ethanol for goats fed experimental diets. The rumen $\mathrm{pH}$ measured for the goats were not significant $(p>0.05)$ among treatments at neutral $\mathrm{pH}$ scale, this is an indication for low rumen acid level. Total volatile fatty acids increased $(p>0.05)$ with increased levels of treated municipal organic waste (TMOW). Acetic acids rumen content was significant $(p<0.01)$ among treatments. Treatment $C$ and $B$ showed higher $(p<0.05)$. The butyric acids rumen contents of treatments $B$ and $C$ was $(p<0.01)$ higher over the $A$ treatment. Ethanol obtained from the rumen contents of treatments $B$ and $C$ were $(p<0.01)$ lower than as shown in treatment $A$. While propionic was found to increase $(p>0.05)$ with increased levels of treated municipal organic waste.

\subsection{Rumen Mineral Electrolytes Content}

Potassium (K), sodium ( $\mathrm{Na}$ ) and calcium $(\mathrm{Ca})$ were noted to increase $(p<0.01)$ with increasing levels of treated municipal organic waste (Table 4), and shown $(p<0.05$, and $\mathrm{p}<0.01$ ), respectively. Higher values were generally found among the treatment $C$, followed by $B$ and $A$, respectively.

\subsection{Rumen Moisture Content, Dry Matter and Fat (Ether extract)}

Rumen moisture content, dry matter and fat (ether extract) of the goats fed experimental diets were as presented in Table 5. Higher rumen moisture content was obtained $(p<0.01)$ for goats fed diet $B$, over those of the diets $C$ and $\operatorname{diet} A$, respectively. There were $(p<0.05)$ differences on the dry matter and fat rumen content as observed among goats fed experimental diets.

\section{DISCUSSION}

\subsection{Microbial Counts}

As noted in this study, there was an increased bacteria count for goats fed treated municipal organic waste at $70 \%$ level of inclusion, while those fed at $45 \%$ inclusion revealed lower microbial load count $(p<0.05)$. This conformed with previous findings that over $70 \%$ of the total rumen microorganisms are bacteria, which play an important role in host nutrition, physiology and immunity of the animals [38]. Metagenomics analysis of rumen microorganisms of cattle of different ages also revealed that highly represented group were bacteria and was noted at $85 \%$, and that, the much lower abundance were Archaea [39]. In the aspect of solid-state fermentation and substrate degradation of cellulose, fibrous and lignocellulose feed stuffs, this is only achievable by the use of microorganisms that are mainly anaerobes [40]. Extra-ruminal nutrient fermentation using snail (Achachatina achachatina) as pre-feeding biodegradation of sawdust and crop waste, must have affected the rumen microbial population by increasing its multiplication. The complex nature of these increase bacteria interactions between that of snail and rumen microbes, can be best explain with the state-of-the-art methodologies for quantifying heterotrophic bacteria productivity [5]. Bacteria cells that can better exploit their 
Table 1. Composition and chemical analysis of the experimental diets

\begin{tabular}{|c|c|c|c|}
\hline Feedstuffs & Diets (\%) & & \\
\hline & $\mathbf{A}$ & B & C \\
\hline Untreated Municipal Organic Waste & 45.00 & - & - \\
\hline Treated Municipal Organic Waste & & 45.00 & 70.00 \\
\hline Wheat offal & 22.5 & 22.5 & 10.00 \\
\hline PKC & 22.5 & 22.5 & 10.00 \\
\hline Molasses & 10.00 & 10.00 & 10.00 \\
\hline Total & 100 & 100 & 100 \\
\hline \multicolumn{4}{|l|}{ Chemical component analysis } \\
\hline Protein & $14.31^{\mathrm{c}}$ & $15.56^{\mathrm{a}}$ & $14.69^{b}$ \\
\hline Fat & $9.75^{a}$ & $7.09^{c}$ & $9.16^{\mathrm{b}}$ \\
\hline Ash & $17.74^{b}$ & $17.47^{\mathrm{c}}$ & $23.86^{a}$ \\
\hline Sugar & $0.99^{a}$ & $0.18^{c}$ & $0.28^{b}$ \\
\hline Starch & $7.20^{\mathrm{a}}$ & $4.55 \mathrm{c}$ & $7.10 \mathrm{~b}$ \\
\hline Cellulose & $9.64^{a}$ & $7.88^{\mathrm{b}}$ & $10.00^{a}$ \\
\hline Hemicellulose & $9.41^{a}$ & $7.02^{b}$ & $3.42^{c}$ \\
\hline Lignin & $5.81^{\mathrm{b}}$ & $4.38^{\mathrm{c}}$ & $5.90^{\mathrm{a}}$ \\
\hline Energy $(\mathrm{MJ} / \mathrm{kg})$ & $12.20^{\mathrm{a}}$ & $6.06^{c}$ & $7.71^{\mathrm{b}}$ \\
\hline \multicolumn{4}{|l|}{ Macro-nutrients (\%) } \\
\hline Nitrogen & $2.29^{\mathrm{c}}$ & $2.49^{\mathrm{a}}$ & $2.35^{\mathrm{b}}$ \\
\hline Phosphorus & $0.60^{\mathrm{b}}$ & $0.71^{\mathrm{a}}$ & $0.59^{\mathrm{c}}$ \\
\hline Calcium & $1.09^{c}$ & $1.59^{\mathrm{b}}$ & $2.30^{\mathrm{a}}$ \\
\hline Potassium & $1.55^{\mathrm{a}}$ & $1.59^{\mathrm{b}}$ & $0.94^{c}$ \\
\hline Magnesium & $0.28^{a}$ & $0.21^{\mathrm{b}}$ & $0.13^{c}$ \\
\hline Sulphur & $0.21^{b}$ & $0.13^{c}$ & $0.31^{\mathrm{a}}$ \\
\hline \multicolumn{4}{|l|}{ Micro-minerals (mg/kg) } \\
\hline Sodium & $15.82^{c}$ & $16.87^{b}$ & $26.38^{a}$ \\
\hline Manganese & $0.28^{\mathrm{a}}$ & $0.21^{\mathrm{b}}$ & $0.13^{c}$ \\
\hline Iron & $2050.05^{c}$ & $2794.65^{b}$ & $4130.90^{\mathrm{a}}$ \\
\hline Cobalt & $0.80^{\mathrm{c}}$ & $1.36^{\mathrm{b}}$ & $2.03^{a}$ \\
\hline Copper & $18.00^{c}$ & $20.20^{\mathrm{b}}$ & $22.20^{a}$ \\
\hline Zinc & $49.10^{c}$ & $56.70^{\mathrm{b}}$ & $58.28^{a}$ \\
\hline
\end{tabular}

Table 2. Microbial load count (Cfu/mg) in rumen content

\begin{tabular}{lllllc}
\hline Parameter & A & B & C & SEM & Sig. \\
\hline Bacteria & $132.33 \times 10^{8 \mathrm{~b}}$ & $122.33 \times 10^{8 \mathrm{c}}$ & $146.33 \times 10^{8 \mathrm{a}}$ & $6.96 \times 10^{8}$ & ${ }^{*}$ \\
Protozoa & $34.33 \times 10^{4 \mathrm{~b}}$ & $41.33 \times 10^{4 \mathrm{a}}$ & $32.00 \times 10^{4 \mathrm{~b}}$ & $2.79 \times 10^{4}$ & ${ }^{*}$ \\
Fungi & $2.33 \times 10^{3 \mathrm{a}}$ & $1.67 \times 10^{3 \mathrm{~b}}$ & $2.33 \times 10^{3 \mathrm{a}}$ & 99.4 & ${ }^{*}$ \\
\hline${ }^{*}=$ Significant $(P<0.05) ;{ }^{* *}=$ Significant $(P<0.01)$, a.b.c Means in the same row with different letters superscripts \\
& are Significant $(P<0.05 ;$ P $P$ < 0.01$)$, SEM: standard mean error
\end{tabular}

Table 3. Rumen pH, total volatile acids (TVA), acetic acid, butyric and ethanol levels of goats fed experimental diets

\begin{tabular}{|c|c|c|c|c|c|}
\hline Sample & $\mathbf{A}$ & B & C & SEM & Sig. \\
\hline $\mathrm{pH}$ & 6.8 & 6.8 & 6.7 & 0.0093 & ns \\
\hline Total VFA (mmol) & 102 & 106 & 110 & 2.60 & ns \\
\hline Acetic $(\mathrm{mmol} / \mathrm{g})$ & $0.44^{c}$ & $0.58^{b}$ & $0.66^{a}$ & 0.0002 & * \\
\hline Butyric $(\mathrm{mmol} / \mathrm{g})$ & $0.08^{b}$ & $0.12^{a}$ & $0.12^{\mathrm{a}}$ & 0.0002 & ** \\
\hline Ethanol $(\mathrm{mmol} / \mathrm{g})$ & $0.34^{a}$ & $0.13^{c}$ & $0.22^{b}$ & 0.0002 & ** \\
\hline Propionic $(\mathrm{mmol} / \mathrm{g})$ & 0.69 & 0.74 & 0.78 & 0.0003 & ns \\
\hline
\end{tabular}


Table 4. Selected rumen electrolytes contents of goats fed experimental diets

\begin{tabular}{llllll}
\hline Parameter (mg/100g) & A & B & C & SEM & Sig. \\
\hline $\mathrm{K}$ & $95.00^{\mathrm{b}}$ & $104.33^{\mathrm{b}}$ & $121.17^{\mathrm{a}}$ & 0.93 & ${ }^{*}$ \\
$\mathrm{Na}$ & $70.12^{\mathrm{b}}$ & $93.67^{\mathrm{b}}$ & $102.33^{\mathrm{a}}$ & 32.23 & ${ }^{*}$ \\
$\mathrm{Ca}$ & $55.99^{\mathrm{b}}$ & $69.67^{\mathrm{a}}$ & $69.69^{\mathrm{a}}$ & 21.00 & ${ }^{*}$ \\
\hline
\end{tabular}

${ }^{*}=$ Significant $(P<0.05) ;{ }^{* *}=$ Significant $(P<0.01)$, a.b.c Means in the same row with different letters superscripts are Significant $(P<0.05 ; P<0.01)$, SEM: Standard mean error

Table 5. Rumen moisture, dry matter and fat content of goats fed experimental diets

\begin{tabular}{lllllc}
\hline Sample (\%) & A & B & C & SEM & Sig. \\
\hline Moisture & $9.47^{\mathrm{c}}$ & $19.13^{\mathrm{a}}$ & $11.52^{\mathrm{b}}$ & 0.272 & ${ }^{*}$ \\
Dry Matter & $90.53^{\mathrm{a}}$ & $80.87^{\mathrm{b}}$ & $88.48^{\mathrm{a}}$ & 0.400 & ${ }^{*}$ \\
Fat & $1.27^{\mathrm{a}}$ & $1.07^{\mathrm{b}}$ & $1.15^{\mathrm{a}}$ & 0.00052 & ${ }^{*}$ \\
\hline${ }^{*}=$ Significant & $(P<0.05) ;{ }^{* *}=$ Significant & $(P<0.01)$, a.b.c & Means in the same row with different letter superscripts \\
& are Significant $(P<0.05 ;$ & $P<0.01)$, SEM: Standard mean error
\end{tabular}

environment will potentially produce more progeny. However, cells encountering suboptimal environments relative to their metabolic adaptations, will be out competed. Growth and occupancy of any community is defined by flexible metabolic strategies based on the external environment [6]. The drivers of these microenvironments are resource gradients including nutrients, $\mathrm{pH}$, physical space, reducing agents, and terminal electron acceptors as noted by Rousk et al., [41], Goldfarb et al., [42], De Weirdt and Van de Wiele, [43]. This is to say that bacteria may inhibit or kill competitors and prevent invasion into their territory, through interference competition, releasing diffusible antagonist such as, toxins or antibiotics. They can create inhospitable zones for competitors [44]. Just as an in-vitro laboratory process, that best explained the interaction of single cell bacteria culture communities, which involves one set developing biofilm as protective shield against the other. So, it is possible to have such in-vitro bacteria mechanism in a complex microbial communities. The interaction from pre-feeding diastic-microbes of snail fermentation, and invivo ruminal microbial fermentation can lead to increased bacteria load 9 [7]. On the extracellular polysaccharides (EPS) microbes of snail, exploiters can compete their isogenic cousins from rumen as in this study [1].

Rumen protozoa are known to engulf bacteria and feed particles and digest carbohydrates, proteins, fats and cellulose [45]. Treatment diets $B$ shows higher protozoa cells counts. It conforms with other findings from several authors which estimated $<50 \%$ rumen protozoa cells count. Nagaraja [8] reported that, protozoa genus Entodinium to have been involved in control of bacterial populations in the rumen, as obtained in low bacteria population for treatment diet $\mathrm{B}$. These ciliates organisms play an important role in fibre digestion and the modulation of the fermentation profiles [46]. It has been difficult to establish the role of ciliate protozoa in rumen fibre degradation based on Newbold et al., [47]. Hopefully, recent technological advancement in microbial biotechnology research will go a long way in solving these microbial mysteries. Rumen anaerobic fungi constitute $5-8 \%$ of the total biomass. Anaerobic fungi will attach through flagella, encyst, and develop a rhizoidal system, which penetrates the substrates with the help of polysaccharidedegrading enzymes [48]. The zoospores attachment takes place within 15-30 minutes of incubation of feed in the rumen. Then secretes an array of enzymes including esterases (feruloyl esterase, $\rho$-coumaryl esterases, and acetyl esterase), which break the ester bonds between hemicelluloses and lignin, thus releasing free celluloses and hemicelluloses for the other microbes to attack [49]. The fungi have been known to produce multienzyme complex known as cellulosomes [50,51]. This characteristic drew the attention for biotechnological applications as well as for microbial supplementation of feeds for ruminant production, and for improving low-quality feeds in livestock production as in this study [5]. Inclusion of anaerobic fungi cultures in diets has been made and the results indicated improvement in feed intake, animal growth rate, feed efficiency, and increased milk production $[52,48,5]$. 


\subsection{Rumen pH}

Rumen $\mathrm{pH}$ close to it buffer level at a favourable microbial growth stage. This is similar to Aluwang et al., [53] as in the $\mathrm{pH}$ of gastrointestinal tract, with the exception of the stomach, is nearly neutral, where $90-99 \%$ of short chain fatty acids (SCFAs) were presented as anions rather than as free acids. It is good to note that, too low $\mathrm{pH}$ creates an acidic rumen ecological environment, that is unfavourable for microorganism to thrive, except acidophilic microbes which cause acidosis. High $\mathrm{pH}$ creates an alkaline rumen ecological environment, which hamper the growth and reproduction of microorganisms. Some extreme acidophiles typically growing at $\mathrm{pH}<3$ or within 0.5 to 5 , and others are moderate with an optimal growth 3 to $5 \mathrm{pH}[54,55]$. For alkaliphilic or alkaliphiles $\mathrm{pH}$ are in range of 9 to 12 . Most bacteria are neutrophiles that grow in $\mathrm{pH} 5.5$ to 8.5 or 5 to 9 [55]while fungi thrive at slightly acidic pH values of 5.0 to 6.0 . The group of acidophiles are higly versatile and are able to utilize wide variety of energy sources (solar, inorganic and organic chemicals). They grow in the presence or complete absence of oxygen, and at the temperature between $4^{\circ} \mathrm{C}$ and $96^{\circ} \mathrm{C}[56,57]$. At acidophilic and alkaliphilic levels, any microbes that survives make the rumen ecological environment difficult for actual fermentation and breakdown of fibrous mats. An extreme $\mathrm{pH}$ affects the structure of all macromolecules and the living cells. The hydrogen bonds holding together strands of DNA breakup at high $\mathrm{pH}$, especially the protein most sensitive to $\mathrm{pH}$ in the cell workhouse. It is clear to note that, moderate changes in $\mathrm{pH}$ modify the ionization of amino-acid functioning groups and disrupt hydrogen bonding, and cause changes in the folding of the molecules, promoting denaturation and destroying activity. The study on ruminal $\mathrm{pH}$ helped to identify risk factors of subacute ruminal acidosis in dairy herds [58]. Note that, the percentage concentrates in the ration, days in milk, (DIM), time of day, and daily milk yield are factors affecting ruminal $\mathrm{pH}$ at herd level [59].

\subsection{Total Volatile Fatty Acids}

Total volatile fatty acids (VFAs) are produced in large amounts through ruminal fermentation and are importance in that, they provide about $70 \%$ of the ruminant energy supply to function metabolically. It well proven that, continuous removal of VFA from the rumen is important not only for distribution, but to prevent excessive and damaging drops in $\mathrm{pH}$ of rumen fluid, which may cause acidosis. High proportions of rumen volatile fatty acids (acetate, propionic and butyric) found in young Friesian bulls 2 hours after post-feeding with mixed rations of low-degraded neutral detergent fibre in dry matter content; with peak VFAs for 4 hours in the rumen after feeding [60]. It is an establish facts that, anaerobic microbial fermentation of dietary fibre of complex carbohydrate in the forestomach and large intestine, produce short chain volatile fatty acids (acetic, propionic, butyric, isobutyric, valeric, isovaleric, 2methylbutyric, hexanoic and heptanoic acid) was note as in Aluwong et al., [53]. Acetate, propionate and butyrate are the predominant SCFAs, and were readily available, absorbed and assimilated as nutrient by the ruminant. Ruminants depend on the SCFAs up to $80 \%$ for their energy requirements for maintenance and production [61]. In ruminant, propionate is the major substrate for hepatic gluconeogenesis, where acetate, propionate and butyrate stimulate sodium and fluid absorption in the colon [62].

\subsection{Rumen Minerals Electrolytes, Moisture, Dry Matter, Fat Contents}

Within the rumen, the ability to utilize ingested materials especially from plant origin to release electrolytes in the bonded cells, depends highly on how well the fermentation is constructed and how efficiently the products are removed. Basically, four groups of microorganism which occupy the rumen and enhance the breakdown of the complex plant cells are; bacteria, methanogens, protozoa and fungi this is as revealed by Nagaraja, [8]. As noted in this study, the manipulation of the rumen system to liberate electrolytes is achievable through feed, host animal and microbial biotechnological manipulations [8]. Preferential, degradation of cellulose and hemicellulose is dependent on the type of substrate, duration of degradation and physiological behaviours of the microbes used [63]. As in the studies of Abayomi et al. [63] and Babayomi [64] enhanced digestibility, decreased crude fibre, increased crude protein and electrolytes in maize husk substrates treated with with-rot fungus, in the use of rumen liquid content for incubation as means for pre-degradation process for fibre. The rumen has evolved to be an efficient and complex lignocellulose degradation system, and is considered to be the most efficient 
microbial system at degrading lignocellulosic biomass to liberate electrolytes and other essential nutrients $[65,66]$. This fact has attracted great interest in mining enzymes from rumen environment for use in the industrial processes $[67,68]$. As in this study, selected rumen minerals increased with increased inclusion of treated municipal organic waste. These microbial actions as revealed as in the diets (substrate) must have enhanced the breakdown of complex structure, with electrolytes releasing potassium, sodium and calcium as observed in our study. Elfaki and Abdelatti, [69], reported ether extract of $1.55 \%$, dry matter $97.41 \%$, potassium $0.173 \%$, sodium $0.14 \%$, and calcium $1.20 \%$ for normal healthy goats, which is similar to our study.

\section{CONCLUSION}

Microbial exogenous pre-feeding fermentation (municipal organic waste treated diastic microbes) enhances the breakdown and utilization of municipal waste as feed for goats as in this study (parameters such as potassium, sodium and calcium for rumen electrolytes, dry matter, moisture and fat content, bacteria, protozoa and fungi for rumen ecology and the total volatile fatty acids, $\mathrm{pH}$, propionic acids, ethanol, acetic, and butyric acids for rumen physiology. The microbial biomass contributed directly and indirectly to organic matter degradation. The results of this study revealed that, municipal organic solid waste when treated with diastic microbes would serve as good feed for goat husbandry. This is because, there were general improvements in all parameters studied, when the waste was treated with diastic microbes. Also, further test studies should be conducted on the feeding trials on goats and other ruminants on the treated municipal organic solid waste with diastic microbes from Snails, using more advance state-of-the-art technology.

\section{ACKNOWLEDGEMENTS}

The recognition of the first position in the sample records for Zymomonas mobilis cells in the world by the Worldwide Science.org and the commendation of the Michael Okpara University of Agriculture, Umudike on the above achievements to Professor Nmandi Mbanefo Anigbogu, Who is generally and gratefully acknowledged. The material assistances and expertise on the "Physiology and Microbial Ecology of Goats Fed Municipal Organic Solid
Wastes Treated with Diastic Microbes from Snail (Achatina achatina)" provided by him is well appreciated. The authors also extend many thanks to reference authors and others who in one way contributed to this study.

\section{COMPETING INTERESTS}

Authors have declared that no competing interests exist.

\section{REFERENCES}

1. Henderson G, Cox F, Ganesh S, Jonker A, Young W, Janssen PH. Rumen microbial community composition varies with diet and host, but a core microbiome is found across a wide geographical range. Sci Rep. 2015;5:1-15.

2. McCann JC, Wickersham TA, Loor JJ. High-throughput methods redefine the rumen microbiome and its relationship with nutrition and metabolism. Bioinform. Biol. Insights. 2014;8:109125.

DOI: $10.4137 / B B I . S 15389$

3. Romagnoli EM, Kmit MCD, Chiaramonte JB, Rossmann M, Mentes R. Ecological aspects of rumen microbiome. Springer International Publishing. JI de Azevedo, MC Queline (eds), Diversity and Benefits of microorganisms from the Tropics;2017.

DOI 10.1007/978-3-319-55804-2-16

4. Anigbogu NM, Afam-lbezim EM, Ukweni IA. Exploiting nutrients of sawdust degraded diastic microbes as feed for goats: An alternative municipal organic waste management. Nigeria Agricultural Journal. 2018;49(2):26-33.

Available:www.ajol.info/index.php/naj

5. Anigbogu NM, Agida CA, Chukurah CB, Afam-Ibezim EM, Efuribe BE. Economic impact and growth rate of Red Sokoto goats fed treated municipal organic waste and grass/legume mixtures. Nigerian Journal of Animal Science and Technology. 2020;3(2):253-265.

6. Anigbogu NM, Ogu CC, Agida AC, AfamIbezim EM. Growth and economic benefits of cane rats fed diastic-microbes degraded sawdust: Solid waste management strategy. Nigeria Agricultural Journal. 2019a;50(2):157165.

Available:www.ajol.info/index.php/naj 
7. Firkin JL. Reconsidering rumen microbial consortia to enhance feed efficiency and reduce environmental impact of ruminant livestock production systems. $\mathrm{R}$ Bras Zootec. 2010;39:(4):45-57.

8. Nagaraja TG. Microbiology of the rumen. In: DD. Millen RDL. Pacheco and MDB. Arrigoni (eds.). Rumenology. Springer International publishing Switzerland. 2016;3961.

DOI:10.1007/978-3-319-30533-2

9. Valkenburg C, Walton CW, Thompson BL, Gerber MA, Jones S, Stevens DJ. Municipal solid waste (MSW) to liquid fuels synthesis, Volume 1. Availability of feedstock and Technol. PNNL. 18144. Pacific Northwest National Laboratory, Richland, WA;2008.

10. Miezah K, Obiri-Danso K, Kadar Z, FeiBaffoe B, Mensah MY. Municipal solid waste characterization and quantification as measure towards effective waste management in Ghana. Waste Management. 2015;46:15-27.

11. Nabegu AB. An analysis of municipal solid waste in Kano meteropolis Nigeria. J. Hum. Ecolo. 2010;91(2):111-119.

12. Nagabooshnam JK. Solid waste generation and composition in Gaborone, Bostwana, Potential for resource recovery. Master thesis, Energy and environmental engineering, Department of Management Engineering Linkoping, University, Sweden;2011.

13. Okot-Okumu J. Solid waste management in African Cities-East Africa. Waste Management- An Integrated Vision. ISBN: 978-953-51-0795-8. In Tech;2012.

14. Rosenberg E, Sharon G, Atad I, ZilberRosenbegr I (2010) The evolution of animal and plants via symbiosis with microorganisms. Environ Microbiol Rep. 2:500-506.

15. Rafferty JP, Thompson JN (2016) Enciclopaedia Britannica. Available: Avaliable:http://global.britannica. com/science/coevolution. Accessed on 16 July

16. Crater AR, Barboza PS, Forster RJ. Regulation of rumen fermentation during seasonal fluctuations in food intake of muskoxen. Comp Biochem Physiol a Mol Integr Physiol. 2007;146:233-241.

17. Pulido RG, Muñoz R, Lemarie $P$, Wittwer $F$, Orellana P, Waghorn GC. Impact of increasing grain feeding frequency on production of dairy cows grazing pasture. Livest Sci. 2009;125:109-114.

18. Li M, Penner GB, Hernandez-Sanabria E, Oba M, Guan LL. Effects of sampling location and time, and host animal on assessment of bacterial diversity and fermentation parameters in the bovine rumen. J Appl Microbiol. 2009;107:19241934.

19. Hernandez-Sanabria E, Goonewardene LA, Wang Z, Zhou M, Moore SS, Guan LL. Influence of sire breed on the interplay among rumen microbial populations inhabiting the rumen liquid of the progeny in beef cattle. PLoS One. 2013;8:e58461

20. National Research Council (NUS). The new science of metagenomics: revealing the secrets of our microbial planet. Washington, DC: National Academies Press;2007.

21. Konstantinidis KT, Braff J, Karl DM, DeLong EF. Comparative metagenomic analysis of a microbial community residing at a depth of 4,000 meters at station ALOHA in the North Pacific subtropical gyre. Appl Environ Microbiol. 2009;75:5345-5355.

22. Quince C, Lanzen A, Curtis TP, Davenport RJ, Hall N, Head IM, Read LF, et al. Accurate determination of microbial diversity from 454 pyrosequencing data. Nat Methods. 2009;6:639-641.

23. Singh B, Gautam SK, Verma V, Kumar $M$, Singh B. Metagenomics in animal gastrointestinal ecosystem: potential biotechnological prospects. Anaerobe. 2008;14:138.

24. Dar MA, Pawar KD, Pandit RS. Gut microbiome analysis of snails: a biotechnology approach. Organismal and molecular malacology;2017.

Available:http://dx.org/10.5772/68133

25. Eric Benbow M, Jenifer L. Pechal, Amelia K. Ward. Heterotrophic Bacteria Production and Microbial Community Assessment. Editor(s): F. Richard Hauer, Gary A. Lamberti, Methods in Stream Ecology. Volume 1 (Third Edition), Academic Press, 2017; Chapter 9:161176.

26. National Root Crops Research Institute. Agro-Meteorological Unit, Umudike, Umuahia, Abia State, Nigeria; 2017. 
27. A.O.A.C. Association of official and analytical chemists. Official methods of Analysis; 2015.

28. Jennische $\mathrm{P}, \quad$ Larsson K. Traditionellasvenskaanalysmetodor for foderochväxtmaterial. SLL metod. 1990;60.

29. Hassan JAG, El Tinay ALI. Food Chemistry. 1995;53:149-151.

30. Van Soest PJ. Nutritional ecology of ruminants. Corvallis, OR, USA; $\mathrm{O}$ and $\mathrm{B}$ Books; 1982.

31. Nordkvist E. Bestam ingavstarkelse med termostabilitamylas. SLL Metod. 1989;38.

32. Bengtsson S, Larsson L. Determination of starch in low-injection system with immobized enzymes. Swedish Journal of Agricultural Research. 1990;20:27-29.

33. Anigbogu NM, Uchealor DJ, Eze JCR, Agida CA, Afam-Ibezim EM. Chemical characteristics of source separated municipal organic waste degraded with diastic microbes of Achatina acahatina as animal feed. Journal of Nigerian Environmental Society. 2019b;12(2):5465.

34. Anigbogu NM, lbe SI, Anosike JC. Production of life enzymes (direct fedmicrobes) from sawdust/Zymomonas mobilis as feed for goats. Raw Materials Researches and Development Council, Federal Ministry of Science and Technology Documentation Innovation Fair;2009.

Avaliable:www.rmrdc.gov.ng

35. Mc Sweeney C, Mackie R. Microorganisms and ruminant digestion: state of knowledge, trends and future prospects. Commission on Genetic Resources for Food and Agriculture;2012. www.foa.org

36. Food and Agricultural Organization and Humane Society International. Guidelines for humane handling, transport and slaughter of livestock. FOA of the UN regional office for Asia and the Pacific. compiled by: Chambers PG, Grandin T, Edited by: Heinz S, Srisuvan T. RAP publication;2001.

37. Gomez KA, Gomez AA. Statistical Procedures for Agricultural Research. The International Rice Research Institution 294 pp. Los Banos, Laguna, Philippines;2005.

38. Sha Y, Hu J, Shi B, Dingkoa R, Wang J, Li $S$, Zhang W, Luo Y, Liu X. Characteristic and functions of the rumen microbial community of cattle-yak at different ages. BioMed Research International;2020.

Available:https//doi.org10.1155/2020/3482 692

39. Yuzhu Sha, Jiang Hu, Bingang Shi, Renqing Dingkao, Jiqing Wang, Shaobin $\mathrm{Li}$, Wei Zhang, Yuzhu Luo, and Xiu Liu (2020). Characteristics and Functions of the Rumen Microbial Community of Cattle-Yak at Different Ages. Bio Med Research International.

Available:

https://doi.org/10.1155/2020/3482692

40. Dehority BA. Rumen microbiology. Nottingham University Press, Nottingham;2003.

41. Rousk J, Bååth $E$, Brookes $P C$, Lauber CL, Lozupone C, Caporaso JG, et al. Soil bacterial and fungal communities across a $\mathrm{pH}$ gradient in an arable soil. ISME J. 2010;4:1340-1351. 10.1038/ismej.2010.58

42. Goldfarb KC, Karaoz U, Hanson CA, Santee CA, Bradford MA, Treseder KK, et al. Differential growth responses of soil bacterial taxa to carbon substrates of varying chemical recalcitrance. Front. Microbiol. 2011;2:94

DOI:10.3389/fmicb.2011.00094

43. De Weirdt $R$, Van de Wiele $T$. Micromanagement in the gut: microenvironmental factors govern colon mucosal biofilm structure and functionality. NPJ Biofilms Microbiomes. 2015;1:1502610.

DOI:1038/npjbiofilms.2015.26

44. Stubbendieck RM, Vargas-Bautista C, Straight PD. Bacterial Communities: Interactions to Scale. Frontiers Microbiology. 2016;7:1234.

DOI:10.3389/fmicb.2016.01234.

45. Findley SD, Mormile MR, Sommer-Hurley A, Zhang XC, Tipton P, Arnett K, Porter $\mathrm{JH}$, et al. Activity-based metagenomic screening and biochemical characterization of bovine ruminal protozoan glycoside hydrolases. Appl Environ Microbiol. 2011;77:8106-8113.

46. Koike S, Kobayashi Y. Fibrolytic rumen bacteria: their ecology and functions. Asian Australian Journal of Animal Sciences. 2009;22(1).

DOI: 10.5713/ajas.2009.r.01. 
47. Newbold CJ, Fuente GL, Belanche A, Ramos-Morales E, NR ME. The role of ciliate protozoa in the rumen. Front Microbiol. 2015;6:1-14.

48. Gao AW, Wang HR, Yang JL, Shi CX. The effects of elimination of fungi on microbial population and fiber degradation in sheep rumen. Appl Mech Mater. 2013;295:224-231.

49. Yue Q, Yang HJ, Cao YC, Zhang DF, Jiang YH, Wang JQ. Feruloyl and acetyl esterase production of an anaerobic rumen fungus Neocallimastix sp. YQ2 effected by glucose and soluble nitrogen supplementations and its potential in the hydrolysis of fibrous fetuffs. Anim Feed Sci Technol. 2009;153:263-277.

50. Krause DO, Denman SE, Mackie RI, Morrison M, Rae AL, Attwood, G.T, Mcsweeney CS. Opportunities to improve fiber degradation in the rumen: microbiology, ecology, and genomics. FEMS Microbiol Rev. 2003;27:663-693.

51. Joblin K, Naylor G, Odongo N, Garcia M, Viljoen $G$. Ruminal fungi for increasing forage intake and animal productivity. In: Sustainable improvement of animal production and health. FAO, Rome. 2010;129-136.

52. Anigbogu NM, Ezekem EP. Protein value of life enzyme (Zymomonas mobilis degraded sawdust/poultry litter) cake produced and fed to West African dwarf goats. Journals of Farm Animals. 2011;36(2) 23-27.

53. Aluwong T, Kobo PI, Abdullahi A. Volatile fatty acids production in ruminants and the role of monocarboxylate transporters: A reviews. African Journal of Biotechnology. 2010;9(38):6229-6232.

Available:http://www.academicjournals.or g/AJB

54. Berlemont R, Gerday C. Scientific Fundamentals of Biotechnology. Comprehensive Biotechnology. $\quad 2^{\text {nd }}$ Edition. 2011;229-242.

55. Slonczewski JL. Stress Responses: $\mathrm{pH}$. Encyclopedia of Microbiology. $3^{\text {rd }}$ Edition. 2009;477-484

56. Johnson D. Barrie and aguilera angeles. extremophiles and acidic environments. Encyclopedia of Microbiology. $4^{\text {th }}$ Edition. 2019;206-227.
57. Johnson DD. Extremophiles: Acidic Environments. Encyclopedia of Microbiology. $3^{\text {rd }}$ Edition. 2009;107-126.

58. Oetzel GR. Monitoring and testing dairy herds for metabolic disease. Veterinary Clinic North American Food Animal Practices. 2004;20:651-674.

59. Geishauser T, Linhart N, Neidl A, Reimann A. Factors associated with ruminant ph at herd level. Journal of Dairy Science. 2012;9518:4556-4567.

Available:http://dx.doi.org/10.3168/jds.20 $12-5380$

60. Gruzdev NV, Aluwong T, Markin Yv, Ulivanov EO. Dynamics of ruminal volatile fatty acids in black and white bulls before and after feeding different rations. J. Farm Anim. Select. Feeding, maintenance. 2001;11:24-27.

61. Berger E, Jones WA, Jones DT, Woods DR. Sequencing and expression of a cellodextrinase (ced1) gene from Butyrivibrio fibrisolvens $\mathrm{H} 17 \mathrm{c}$ cloned in Escherichia coli. Mol. Gen. Genet. 1990; 223:310-318.

62. Scheppach W. Effects of short chain fatty acids on gut morphology and function. Gut. Sppl. 1994;1:35-38.

63. Abayomi A, Olaniyi JB, Segun GJ. Bioconversion of Maize Husk into Value Added Ruminant Feed by Using WhiteRot Fungus. Revista UDO Agricola. 2009;9(4):972-978.

64. Babayemi OJ. In vitro fermentation characteristics and acceptability by west African dwarf goats of some dry season forages. Afri. J. Biotechnol. 2007;6(10): 1260-1265.

65. Flint HJ, Bayer EA, Rincon MT, Lamed R, White BA. Polysaccharide utilization by gut bacteria: potential for new insights from genomic analysis. Nat Rev Microbiol. 2008;6:121-131.

66. Morgavi DP, Kelly WJ, Janssen PH, Atwood GT. Rumen microbial (meta) genomics and its application to ruminant production. Anim. 2013;7:184201.

67. Hess M, Sczyrba A, Egan R, Kim TW, Chokhawala $H$, Schroth G, Luo S, et al. Metagenomic discovery of biomass-degrading genes and genomes from cow rumen. Science. 2011;331:463467. 
68. Wang L, Hatem A, Catalyurek UV, Morrison M, Yu Z. Metagenomic insights into the carbohydrate- active enzymes carried by the microorganisms adhering to solid digesta in the rumen of cows. PLOS One 11:e78507 Washington D.C. USA; 2013.
69. Elfaki MOA, Abdelatti KA. Nutritive evaluation of rumen content from cattle, carmel, sheep and goat. Global Journal of Animal Scientific Research. 2015;3(3):617621.

(0) 2021 Agida et al.; This is an Open Access article distributed under the terms of the Creative Commons Attribution License (http://creativecommons.org/licenses/by/4.0), which permits unrestricted use, distribution, and reproduction in any medium, provided the original work is properly cited.

Peer-review history:

The peer review history for this paper can be accessed here:

https://www.sdiarticle4.com/review-history/70290 